\title{
Prevalensi dan Faktor-Faktor Risiko Gangguan Pemusatan Perhatian Anak dan Hiperaktivitas di Klinik Tumbuh Kembang RSUP Sanglah Denpasar
}

\author{
SAK Indriyani, Soetjiningsih, IGA Endah Ardjana, IGA Trisna Windiani \\ Bag/SMF Ilmu Kesehatan Anak FK UNUD/RS Sanglah Denpasar
}

\begin{abstract}
Latar belakang. Gangguan pemusatan perhatian dan hiperaktivitas (GPPH) merupakan gangguan tingkah laku yang paling banyak terjadi pada anak. Angka prevalensi GPPH cukup bervariasi dan terdapat berbagai faktor risiko yang berperan. Deteksi dini sangat diperlukan untuk menegakkan diagnosis sehingga dapat dilakukan intervensi lebih dini.

Tujuan. Mengetahui prevalensi, karakteristik demografi dan klinis, serta faktor-faktor risiko GPPH

Metode. Penelitian bersifat retrospektif dari catatan medik pasien dengan keluhan mengalami masalah tingkah laku, datang ke klinik Tumbuh Kembang RSUP Sanglah periode 2005-2006.

Hasil. Seratus sebelas memenuhi kriteria inklusi, prevalensi GPPH 51 (45,9\%) yang terdiri dari 43 (38,7\%) laki-laki dan 8 (7,2\%) perempuan. Jumlah GPPH tipe kombinasi (A1+A2) 39 (76,5\%), GPPH tipe A1 7 (13,7\%), dan GPPH tipe A2 5 (9,8\%). Anak pertama (PR: 2,88, 95\%CI: 1,33-6,24, $p=0,007)$, tidak mempunyai saudara (PR: 2,69, 95\%CI: 1,19-6,09, $p=0,015)$ dan ibu tamat Sekolah Lanjutan Tingkat Atas (SLTA) dan sarjana $(p=0,02)$ berperan pada GPPH. Jenis kelamin $(p=0,004)$, umur $(p=0,021)$, dan berat badan $(p=0,007)$ berbeda bermakna antara berbagai tipe GPPH.

Kesimpulan. Faktor urutan kelahiran, jumlah saudara dan pendidikan ibu berperan pada GPPH. Jenis kelamin, umur, dan berat badan berbeda bermakna pada ketiga tipe GPPH (Sari Pediatri 2008; 9(5):335-41).
\end{abstract}

Kata kunci: gangguan pemusatan perhatian dan hiperaktivitas, faktor risiko

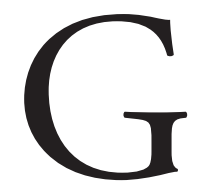

angguan pemusatan perhatian dan hiperaktivitas (GPPH) merupakan gangguan tingkah laku yang paling banyak terjadi pada anak-anak. ${ }^{1-3}$ Para

\section{Alamat korespondensi}

Dr. Sang Ayu K. Indriyani Bag/SMF Ilmu Kesehatan Anak FK UNUD/ RS Sanglah Denpasar Jl. Pulau Nias Denpasar Bali. Telepon/Fax: 0361244038 atau 0361-257387. E-mail: indri_yani22@yahoo.com orangtua baru akan menyadari masalah ini setelah ada masalah seperti prestasi belajar yang kurang atau dipanggil pihak sekolah karena anaknya nakal dan sulit diatur. ${ }^{1}$ Gangguan ini dapat berlanjut saat remaja bahkan sampai dewasa jika tidak mendapat penanganan yang adekuat. ${ }^{1-3}$ Deteksi dini sangat diperlukan untuk menegakkan diagnosis sehingga dapat dilakukan penatalaksanaan lebih dini.

Angka prevalensi GPPH bervariasi, disebabkan 
perubahan kriteria diagnostik yang terus direvisi dan juga perbedaan lokasi geografis serta estimasi sampel yang dipakai. ${ }^{2}$ Berdasarkan revisi terakhir didapatkan angka prevalensi GPPH sebesar 4\%-12\% (dengan estimasi 8\%-10\%) dan terdiri dari 9,2\% (5,8\%13,6\%) laki-laki dan 2,9\% (1,9\%-4,5\%) perempuan. ${ }^{2}$ Menurut klasifikasi Diagnosis and statistical manual of mental disorders (DSM) IV anak perempuan lebih banyak termasuk dalam tipe gangguan perhatian. ${ }^{1,3}$

Data kunjungan rawat jalan di Klinik Tumbuh Kembang RSUP Sanglah Denpasar selama periode 2001 - 2005 menunjukkan peningkatan jumlah kasus GPPH setiap tahun. Jumlah kasus masing-masing berturut-turut tahun $2001-2005$ sebagai berikut 19 $(6,7 \%) ; 32(10,1 \%) ; 40$ (11,2\%); 57 (14,3\%); 71 $(14,1 \%)$. Berdasarkan hal tersebut dilakukan penelitian untuk mengetahui faktor-faktor risiko yang berperan dalam GPPH.

Tujuan penelitian ini adalah untuk mengetahui prevalensi, karakteristik demografi dan klinis, serta faktor-faktor risiko GPPH.

\section{Metode}

Suatu penelitian retrospektif, data diperoleh dari catatan medik pasien yang datang atas keluhan orangtua dan/atau gurunya karena anak mengalami masalah tingkah laku. Penelitian dilaksanakan di Klinik Tumbuh Kembang RSUP Sanglah Denpasar selama periode tahun 2005-2006. Subjek penelitian adalah semua anak yang berkunjung ke Klinik Tumbuh Kembang RSUP Sanglah Denpasar selama periode tersebut yang memenuhi kriteria inklusi dan eksklusi. Kriteria inklusi adalah pasien baru di Klinik Tumbuh Kembang RSUP Sanglah Denpasar selama periode tersebut dengan keluhan masalah tingkah laku oleh orangtua dan/atau gurunya, berumur $\geq 3$ tahun dan $<$ 7 tahun. Kriteria eksklusi adalah catatan medik penderita tidak lengkap, menderita kelainan kongenital berat, sindrom tertentu, palsi serebralis, kurang energi protein (KEP), gagal tumbuh, dan global developmental delay $(G D D)$.

Perhitungan jumlah sampel untuk penelitian deskriptif kategorikal dengan $\alpha<0,05$ dan power penelitian $80 \%$ didapatkan jumlah sampel minimal 94 anak. Definisi GPPH yaitu suatu gangguan yang ditandai dengan ketidakmampuan dalam mempertahankan perhatian, mengatur tingkat aktivitas dan mengontrol tingkah laku impulsif diagnosis ditegakkan berdasarkan DSM IV sebagai attention deficithyperactivity disorder (ADHD) atau GPPH. Tipe GPPH berdasarkan DSM IV antara lain GPPH dengan kesukaran memusatkan perhatian sebagai gejala (kriteria A1 ditemukan tetapi A2 tidak ditemukan dalam 6 bulan terakhir), GPPH dengan hiperaktivitas impulsivitas sebagai gejala utama (kriteria A2 ditemukan tetapi kriteria A1 tidak ditemukan dalam 6 bulan terakhir) dan GPPH tipe kombinasi (kriteria A1 dan A2 ditemukan dalam 6 bulan terakhir). ${ }^{1,2,4}$ Faktor-faktor yang diteliti antara lain urutan kelahiran, jumlah saudara, ${ }^{5}$ berat badan, tinggi badan, lingkar kepala, indeks massa tubuh (IMT) berdasarkan CDC $2000,{ }^{6}$ berat lahir, prematuritas, kelainan bawaan, penyakit menahun yang diderita anak. ${ }^{7-9}$

Sampel yang telah memenuhi kriteria inklusi dan eksklusi dibagi menjadi dua kelompok GPPH dan bukan GPPH berdasarkan kriteria DSM IV (Tabel 1). Penelitian ini disetujui oleh Komite Penelitian dan Pengembangan RSUP Sanglah/FK UNUD Denpasar. Data yang terkumpul diproses dengan sistem komputer.

\section{Hasil}

Selama periode 2005-2006 terdapat 162 catatan medik penderita yang berusia 3 tahun sampai $<7$ tahun, 111 pasien memenuhi kriteria penelitian. Pasien terdiri dari $90(81,1 \%)$ laki-laki dan $21(18,9 \%)$ perempuan, prevalensi GPPH didapat 51 (45,9\%). Diagnosis selain GPPH antara lain kesulitan belajar (5,4\%); autisme $(6,3 \%)$; gangguan cemas perpisahan $(0,9 \%)$; gangguan tingkah laku (3,6\%); gangguan bahasa $(25,2 \%)$; retardasi mental $(11,7 \%)$; normal $(0,9 \%)$. Kelompok GPPH terdiri dari GPPH tipe kombinasi $(\mathrm{A} 1+\mathrm{A} 2) 39$ (76,5\%), GPPH tipe A1 7 (13,7\%), dan GPPH tipe A2 5 (9,8\%). Karakteristik dasar subjek penelitian tertera pada Tabel 2. Dilakukan uji t dan alternatifnya pada karakteristik subjek penelitian. Pada variabel kategorikal diilakukan uji $\mathrm{x}^{2}$ atau Fisher, sehingga didapatkan faktor urutan kelahiran, jumlah saudara dan pendidikan ibu sebagai faktor yang berbeda bermakna antara kelompok GPPH dan bukan GPPH (Tabel 3).

Tingkat pendidikan ibu terbukti berbeda bermakna $(p=0,02)$ antara kelompok GPPH dan bukan GPPH, yaitu ibu tamat SLTA dan sarjana paling 
Tabel 1. Kriteria diagnosis berdasarkan DSM-IV (revisi), $2000^{1}$

Diagnosis harus meliputi adanya tidak dapat memusatkan perhatian atau hiperaktivitas atau impulsivitas

Tidak dapat memusatkan perhatian (A1)

Enam atau lebih dari gejala tidak dapat memusatkan perhatian yang menetap paling sedikit 6 bulan sampai pada derajat terjadinya maladaptive dan tidak sesuai dengan tingkat perkembangan:

- Sering gagal dalam memusatkan perhatian pada hal-hal kecil atau membuat kesalahan/ kecerobohan pada pekerjaan sekolah atau aktivitas lain.

- Sukar mempertahankan perhatian pada tugas atau aktivitas.

- Tidak mendengarkan bila diajak berbicara langsung.

- Tidak mengikuti petunjuk dan gagal menyelesaikan pekerjaan sekolah, tugas atau kewajiban.

- Kesukaran dalam mengatur tugas dan aktivitas.

- Sering menghindari atau enggan terikat pada tugas yang membutuhkan dukungan mental yang terus menerus (pekerjaan sekolah atau pekerjaan rumah).

- Sering menghilangkan benda-benda yang dibutuhkan dalam tugas dan aktivitas.

- Mudah terganggu oleh rangsang luar.

- Sering lupa dalam aktivitas sehari-hari.

Hiperaktivitas dan impulsivitas (A2)

Enam atau lebih gejala hiperaktivitas-impulsivitas yang menetap selama 6 bulan sampai pada derajat terjadinya maladaptive dan tidak sesuai dengan tingkat perkembangan.

- Tampak gelisah dengan tangan atau kaki yang menggeliat-geliat di tempat duduk.

- Sering meninggalkan tempat duduk dimana situasinya diharapkan untuk duduk tenang.

- Sering berlari atau memanjat berlebihan dalam situasi dimana hal itu tidak sesuai.

- Sering mengalami kesulitan bila bermain atau bersenang-senang diwaktu senggang dengan kondisi tenang/ diam.

- Selalu bergerak terus atau berlaku bagaikan didorong oleh mesin.

- Sering bicara berlebihan.

- Sering menjawab dahulu sebelum pertanyaan selesai diajukan,

- $\quad$ Sering sulit menunggu giliran.

- Sering menyela dan memaksakan kehendak pada orang lain (memotong pembicaraan atau permainan).

Semua gangguan tersebut

- Muncul sebelum usia 7 tahun.

- Muncul dalam dua atau lebih keadaan (misal di rumah, sekolah atau tempat kerja)

- Gejala ini tidak terjadi semata - mata dalam perjalanan gangguan perkembangan pervasif, skizofrenia atau gangguan psikotik lainnya.

- Tidak lebih baik bila bersama sama dengan gangguan mental lainnya (misal gangguan mood atau gangguan cemas).

banyak memiliki anak GPPH. Lingkar kepala $(p=0,122)$, pendidikan ayah $(p=0,344)$, prematuritas $(p=0,209)$, kelainan bawaan $(p=0,248)$, penyakit anak $(p=0,109)$, dan penyakit serta psikologis ibu $(p=0,276)$ tidak berbeda bermakna antara kedua kelompok. Sub analisis pada berbagai tipe GPPH dengan uji t dan alternatifnya pada ketiga tipe GPPH menunjukkan faktor jenis kelamin, umur dan BB berbeda bermakna diantara ketiga tipe GPPH (Tabel 4).

\section{Diskusi}

Perbedaan metode penelitian, kriteria dan instrumen diagnostik di beberapa negara mengakibatkan angka prevalensi GPPH cukup bervariasi. ${ }^{2}$ Prevalensi GPPH didapatkan $51(45,9 \%)$, terdiri dari $43(38,7 \%)$ lakilaki dan 8 (7,2\%) perempuan. Berdasarkan kepustakaan, angka prevalensi GPPH sebesar 4\%-12\% dan masing-masing terdiri dari 9,2\% (5,8\%-13,6\%) laki- 
Tabel 2. Karakteristik dasar subjek penelitian

\begin{tabular}{lccc}
\hline \multicolumn{1}{c}{ Karakteristik } & $\begin{array}{c}\text { GPPH } \\
(\mathrm{n}=51)\end{array}$ & $\begin{array}{c}\text { Bukan GPPH } \\
(\mathrm{n}=60)\end{array}$ & $p$ \\
\hline Jenis kelamin, n(\%) & & & \\
$\quad$ C $\quad$ Paki-laki & $43(38,7)$ & $47(42,3)$ & 0,423 \\
Umur, (tahun, rerata(SB)) & $8(7,2)$ & $13(11,7)$ & \\
BB (kg, rerata(SB)) & $4,42(1,36)$ & $4,50(1,27)$ & 0,762 \\
TB (cm, rerata(SB)) & $17,64(5,19)$ & $16,55(3,68)$ & 0,201 \\
IMT (kg/m², rerata(SB)) & $104,11(13,51)$ & $100,07(10,32)$ & 0,077 \\
Lingkar kepala (cm, rerata(SB)) & $16,10(2,49)$ & $16,57(3,05)$ & 0,383 \\
Umur ayah (tahun, rerata(SB)) & $49,73(1,97)$ & $49,34(1,89)$ & 0,299 \\
Umur ibu (tahun, rerata(SB)) & $34,98(6,43)$ & $35,05(5,41)$ & 0,951 \\
Berat lahir (gram, rerata(SB)) & $32,17(6,76)$ & $31,88(5,51)$ & 0,815 \\
Lama rawat setelah lahir (hari, rerata(SB)) & $3061,76(464,93)$ & $3023,33(565,79)$ & 0,700 \\
Keluhan utama kearah hiperaktif, impulsif, & $4,18(6,38)$ & $4,63(9,40)$ & 0,769 \\
inatensi n (\%) & & & \\
\hline
\end{tabular}

SB: Simpangan Baku

* berbeda bermakna jika $p<0,05$

laki dan 2,9\% (1,9\%-4,5\%) perempuan. Prevalensi yang tinggi terjadi karena populasi penelitian ini adalah anak yang berumur 3 sampai di bawah 7 tahun. Diagnosis GPPH dapat ditegakkan minimal pada umur 3 tahun, ${ }^{10}$ sehingga lebih mudah pada anak yang sudah bersekolah. ${ }^{11}$

Karakteristik dasar subjek penelitian menunjukkan tidak terdapat perbedaan yang bermakna antara kelompok GPPH dan bukan GPPH $(p>0,05)$. Penyebab pasti GPPH sampai saat ini masih belum jelas, tetapi diduga bersifat multifaktorial, baik faktor biologis maupun lingkungan. ${ }^{1,3,12,13}$ Suatu penelitian kasus kontrol menyebutkan bahwa faktor jenis kelamin, prenatal (prematur dan preeklampsia), intranatal (asfiksa), neonatal (sepsis, hipoglikemia) merupakan faktor risiko GPPH. ${ }^{13}$

Urutan kelahiran terbukti berbeda bermakna antara kelompok GPPH dan bukan GPPH (PR: 2,88, 95\%CI: 1,33;6,24, $p=0,007)$, yaitu anak pertama lebih banyak pada kelompok GPPH. Penelitian GPPH di populasi menunjukkan bahwa jumlah saudara lebih atau sama dengan satu proporsinya lebih banyak $(58,7 \%)$ dibandingkan dengan yang tidak memiliki saudara. ${ }^{5}$ Saat seorang anak mulai memiliki adik dan berkurangnya perhatian kedua orangtua bisa menjadi faktor yang berperan dalam terjadinya GPPH. Jumlah saudara berbeda bermakna antara kedua kelompok, yaitu kelompok GPPH lebih banyak tidak memiliki saudara (PR: 2,69, 95\%CI: 1,19;6,09, $p=0,015)$, suatu penelitian kasus kontrol memberikan hasil yang serupa. Belum ada teori yang jelas mengenai peran saudara pada GPPH, tetapi yang jelas adanya masalah dan ketidaknyamanan dalam lingkungan keluarga merupakan faktor penting yang berperan dalam GPPH. ${ }^{13,14}$

Penelitian di Amerika Serikat melaporkan kejadian GPPH pada populasi anak Sekolah Dasar menunjukkan GPPH didapatkan secara bermakna pada ibu dengan pendidikan sarjana $(p<0,05) \cdot{ }^{11}$ Hasil penelitian menunjukkan pendidikan ibu tamat SLTA dan tamat sarjana terbukti bermakna pada GPPH $(p=0,02)$. Meskipun dasar teori tentang hal ini juga belum jelas, kemungkinan bahwa ibu dengan pendidikan tinggi cenderung untuk bekerja. Suatu penelitian menunjukkan bahwa anak dengan ibu yang bekerja di luar rumah sehingga pengasuhan anak mereka diserahkan kepada pembantu rumah tangga memiliki risiko lebih besar untuk mengalami gejala hiperaktif yang berat $(O R: 2,07,95 \% C I: 1,17 ; 3,69){ }^{5}$

Jenis kelamin berbeda secara bermakna diantara ketiga tipe GPPH $(p=0,004)$. GPPH lebih sering terjadi pada anak laki-laki. ${ }^{1-4,11,15}$ Perkiraan rasio antara laki-laki dan perempuan sebesar 3:1 dan 4:1 pada populasi klinik, serta 2:1 di komunitas. Rasio ini makin menurun beberapa tahun terakhir karena diagnosis GPPH makin baik sehingga terjadi peningkatan diagnosis GPPH tipe A1. GPPH tipe ini lebih banyak terjadi pada anak perempuan dan cukup jarang 
Tabel 3. Faktor-faktor yang berhubungan dengan Gangguan pemusatan perhatian \& hiperaktivitas (GPPH)

\begin{tabular}{|c|c|c|c|c|}
\hline Karakteristik & $\begin{array}{l}\text { GPPH } \\
(\mathrm{n}=51)\end{array}$ & $\begin{array}{c}\text { Bukan GPPH } \\
(\mathrm{n}=60)\end{array}$ & $\begin{array}{c}P R \\
(95 \% C I) \\
\end{array}$ & $p$ \\
\hline \multicolumn{5}{|l|}{ Jenis kelamin, n(\%) } \\
\hline - Laki-laki & $43(38,7)$ & $47(42,4)$ & 1,49 & \multirow[t]{2}{*}{0,423} \\
\hline - Perempuan & $8(7,2)$ & $13(11,7)$ & $(0,56 ; 3,93)$ & \\
\hline \multicolumn{5}{|l|}{ Urutan kelahiran, $\mathrm{n}(\%)$} \\
\hline - Pertama & $31(27,9)$ & $21(19,0)$ & 2,88 & \multirow[t]{2}{*}{$0,007^{*}$} \\
\hline - Kedua atau lebih & $20(18,0)$ & $39(35,1)$ & $(1,33 ; 6,24)^{\#}$ & \\
\hline \multicolumn{5}{|l|}{ Jumlah saudara, n(\%) } \\
\hline • Tidak mempunyai saudara & $23(20,7)$ & $14(12,6)$ & 2,69 & \multirow[t]{2}{*}{$0,015^{*}$} \\
\hline - Mempunyai satu saudara atau lebih & $28(25,2)$ & $46(41,4)$ & $(1,19 ; 6,09)^{\#}$ & \\
\hline \multicolumn{5}{|l|}{ Klasifikasi IMT, n (\%) } \\
\hline • Normal & $38(34,2)$ & $39(35,1)$ & $1,46^{\mathrm{a}}$ & \multirow[t]{2}{*}{0,507} \\
\hline - Kekurangan BB & $6(5,4)$ & $9(8,1)$ & $(0,47 ; 4,50)$ & \\
\hline - Kelebihan BB & $7(6,3)$ & $12(10,8)$ & $1,67^{b}$ & 0,328 \\
\hline \multicolumn{5}{|l|}{ Umur ayah, tahun, $n(\%)$} \\
\hline$\cdot \leq 35$ & $30(26,9)$ & $33(29,8)$ & 1,17 & \multirow[t]{2}{*}{0,685} \\
\hline$\cdot>35$ & $21(19,0)$ & $27(24,3)$ & $(0,55 ; 2,49)$ & \\
\hline \multicolumn{5}{|l|}{ Umur ibu, tahun, $n(\%)$} \\
\hline$\cdot \leq 35$ & $37(33,3)$ & $45(40,5)$ & 0,80 & \multirow[t]{2}{*}{0,619} \\
\hline$\cdot \quad>35$ & $14(12,6)$ & $15(13,6)$ & $(0,34 ; 1,89)$ & \\
\hline \multicolumn{5}{|l|}{ Cara persalinan, $\mathrm{n}(\%)$} \\
\hline Spontan & $33(29,7)$ & $49(44,1)$ & $0,45^{\mathrm{e}}$ & \multirow[t]{2}{*}{0,082} \\
\hline - Seksio sesaria & $15(13,6)$ & $10(9,0)$ & $(0,18 ; 1,12)$ & \\
\hline - Ekstraksi vakum & $3(2,7)$ & $1(0,9)$ & $\begin{array}{c}0,22^{\mathrm{f}} \\
(0,02 ; 2,25)\end{array}$ & 0,304 \\
\hline \multicolumn{5}{|l|}{ Berat lahir, gram, n(\%) } \\
\hline - $<2500$ & $4(3,6)$ & $8(7,2)$ & 0,57 & \multirow[t]{2}{*}{0,353} \\
\hline • $\quad \geq 2500$ & $47(42,3)$ & $52(46,9)$ & $(0,16 ; 1,96)$ & \\
\hline \multicolumn{5}{|l|}{ Lahir langsung menangis, $\mathrm{n}(\%)$} \\
\hline - Ya & $42(37,8)$ & $54(48,7)$ & 0,52 & \multirow[t]{2}{*}{0,240} \\
\hline • Tidak & $9(8,1)$ & $6(5,4)$ & $(0,17 ; 1,57)$ & \\
\hline \multicolumn{5}{|l|}{ Lama rawat setelah lahir, hari, n(\%) } \\
\hline$\cdot \leq 3$ & $36(32,4)$ & $45(40,4)$ & 0,80 & \multirow[t]{2}{*}{0,602} \\
\hline - $>3$ & $15(13,6)$ & $15(13,6)$ & $(0,35 ; 1,85)$ & \\
\hline
\end{tabular}

* bermakna jika $p<0,05$

\# bermakna jika $P R$ tidak melewati angka 1

\$dilakukan dengan uji Fisher

${ }^{a}$ IMT normal berbanding kekurangan BB

${ }^{\mathrm{b}}$ IMT normal berbanding dengan kelebihan BB

${ }^{\text {e }}$ Persalinan spontan berbanding seksio saesaria

${ }^{\mathrm{f}}$ Persalinan spontan berbanding ekstraksi vakum

PR: Prevalence Ratio

terdiagnosis sebelumnya karena tidak terdapatnya hiperaktivitas dan impulsivitas yang biasanya membawa orangtua datang anaknya ke tempat pelayanan kesehatan. ${ }^{2.3,10}$

Kejadian 30\%-50\% anak dengan GPPH akan berlanjut sampai dewasa. Gejala hiperaktif akan menurun sesuai dengan bertambahnya usia karena berkembangnya sistem kontrol diri dan proses maturasi, sedangkan gejala gangguan perhatian menetap hingga dewasa. ${ }^{5,14}$ Mungkin hal tersebut dapat menjelaskan faktor umur juga berbeda bermakna antara ketiga tipe GPPH $(p=0,021)$.

Berat badan pada kelompok GPPH tipe A2 memiliki rerata yang paling kecil dan ini berbeda bermakna jika dibandingkan dengan tipe yang lain $(p=0,007)$. Suatu penelitian menunjukkan bahwa anak 
Tabel 4. Karakteristik berbagai tipe Gangguan pemusatan perhatian \& hiperaktivitas (GPPH)

\begin{tabular}{lcccc}
\hline \multicolumn{1}{c}{ Karakteristik } & $\begin{array}{c}\text { GPPH tipe A1 } \\
(\mathrm{n}=7)\end{array}$ & $\begin{array}{c}\text { GPPH tipe A2 } \\
(\mathrm{n}=5)\end{array}$ & $\begin{array}{c}\text { GPPH tipe } \\
\text { kombinasi }(\mathrm{n}=39)\end{array}$ & $p$ \\
\hline Jenis kelamin, n (\%) & & & & \\
$\quad \quad \quad$ Laki-laki & $3(5,9)$ & $5(9,8)$ & $35(68,7)$ & $0,004^{*}$ \\
Perempuan & $4(7,8)$ & 0 & $4(7,8)$ & \\
Umur, tahun, rerata(SD) & $5,72(0,84)$ & $4,08(1,00)$ & $4,24(1,36)$ & $0,021^{*}$ \\
BB, kg, rerata(SD) & $23,14(7,54)$ & $15,90(3,36)$ & $17,64(5,19)$ & $0,007^{*}$ \\
TB, cm, rerata(SD) & $114,29(6,63)$ & $96,80(9,12)$ & $103,22(13,51)$ & 0,058 \\
IMT, kg/m ${ }^{2}$ rerata(SD) & $17,59(5,07)$ & $16,94(2,52)$ & $15,72(1,68)$ & 0,138 \\
Lingkar kepala, cm, rerata(SD) & $51,29(1,98)$ & $49,00(1,00)$ & $49,54(1,96)$ & 0,064 \\
Umur ayah, tahun, rerata(SD) & $40,00(9,33)$ & $34,80(3,11)$ & $34,10(5,85)$ & 0,080 \\
Umur ibu, tahun, rerata(SD) & $31,14(13,87)$ & $34,40(5,12)$ & $32,05(5,11)$ & 0,707 \\
Berat lahir, gram, rerata(SD) & $2978,57(601,29)$ & $3260,00(545,89)$ & $3051(435,21)$ & 0,571 \\
Lama rawat setelah lahir, hari, rerata(SD) & $9,00(15,92)$ & $3,40(1,52)$ & $3,41(6,38)$ & 0,097 \\
\hline
\end{tabular}

* berbeda bermakna jika $p<0.05$

dengan GPPH secara bermakna memiliki berat badan $5 \mathrm{~kg}$ di bawah anak normal $(44 \pm 18$ berbanding $49 \pm 13$ $\mathrm{kg}, p=0,015) .{ }^{16}$ Hiperaktivitas dan impulsivitas yang dominan pada tipe A2 dapat menjelaskan hal itu bisa terjadi. ${ }^{13}$ Faktor prenatal seperti paparan rokok, minuman keras, gangguan psikiatri selama hamil ${ }^{1}$ dan faktor intranatal seperti prematuritas ${ }^{14,15}$ dan berat lahir yang rendah (terutama kurang dari 1000 gram) berhubungan dengan GPPH. ${ }^{1,14,17} \mathrm{Hal}$ ini tidak terbukti dalam penelitian ini karena jumlah subjek yang prematur hanya 2 yang semua dalam kelompok GPPH, sedangkan subjek dengan berat lahir kurang dari 1000 gram tidak ada. Adanya penyakit yang diderita anak setelah lahir tidak berbeda bermakna pada kelompok GPPH dan bukan GPPH $(p=0,109)$. Suatu penelitian lain menyebutkan bahwa anak dengan GPPH sering memiliki riwayat eksim, asma, dan penyakit alergi lainnya. ${ }^{18}$ Kelemahan penelitian ini adalah penelitian potong lintang dan retrospektif sehingga hasilnya hanya dalam bentuk prevalensi dan rasio prevalen, catatan medik kurang lengkap sehingga beberapa faktor yang ingin diteliti tidak didapatkan datanya, dan periode penelitian yang cukup singkat.

\section{Kesimpulan}

Penelitian retrospektif untuk mendapatkan data dasar kasus GPPH yang ada di Klinik Tumbuh Kembang RSUP Sanglah Denpasar. Faktor urutan kelahiran, jumlah saudara dan pendidikan ibu berperan pada kasus GPPH. Jenis kelamin, umur, dan berat badan berbeda pada ketiga tipe GPPH. Penelitian yang bersifat prospektif dalam periode waktu yang lebih panjang sangat diperlukan sebagai penelitian lanjutan sehingga dapat diidentifikasi faktor-faktor lain yang mungkin berhubungan dengan GPPH yang tidak didapatkan datanya secara retrospektif.

\section{Daftar Pustaka}

1. Rappley, MD. Attention deficit-hyperactivity disorder. N Engl J Med 2005; 352:165-73.

2. American Academy of Pediatrics. Clinical practice guideline: Diagnosis and evaluation of the child with attention-deficit/ hyperactivity disorder. Pediatrics 2000; 105:1158-70.

3. Montauk SL, Mayhall C. Attention-deficit/hyperactivity disorder [diakses 6 Nov 2005]. Didapat dari: URL:http://www.emedicinehealth.com/articles/4174310.asp

4. Cigna HealthCare Coverage Position. Attention-deficit/ hyperactivity disorder (ADHD): Assessment and treatment. MMWR Morb Mortal Wkly Rep 2005; 54:8427.

5. Romano E, Tremblay RE, Farhat A, Cote S. Development and prediction of hyperactive symptoms from 2 to 7 years in a population-based sample. Pediatrics 2006; 117:2101-10.

6. Soetjiningsih, Suandi IKG, Dwilingga. Petunjuk pemeriksaan fisik pada bayi dan anak Lab/SMF Ilmu 
Kesehatan Anak FK UNUD/RS Sanglah; 51-67.

7. Soetjiningsih. Palsi serebralis. Dalam: Ranuh IGNG, penyunting. Tumbuh kembang anak. Cetakan II. Jakarta: Penerbit Buku Kedokteran EGC; 1998. h. 22335.

8. Rudolf MCJ, Logan S. What is the long term outcome for children who fail to thrive? A systematic review. Arch Dis Child 2005; 90:881-8.

9. Shevell M, Ashwal S, Donley D. Practice parameter: Evaluation of the child with global developmental delay. J Neurol 2003; 60:367-80.

10. Zametkin AJ, Ernst M. Problems in the management of attention-deficit- hyperactivity disorder. N Engl J Med 1999; 340:40-6.

11. Schneider H, Eisenberg D. Who receives a diagnosis of Attention-deficit/hyperactivity disorder Attention-deficit/ hyperactivity disorder in the United States Elementary School population? Pediatrics 2006; 117(4):e601-9.

12. Kidd PM. Attention deficit/ hyperactivity disorder (ADHD) in children: Rationale for its integrative management [diakses 6 Nov 2005]. Didapat dari: URL:http:/ /www.findarticles.com
13. Landgren M, Kjellman B, Gillberg C. Attention deficit disorder with developmental coordination disorders. Arch Dis Child 1998; 79:207-12.

14. Gillberg C. Deficits in attention, motor control, and perception: a brief review. Arch Dis Child 2003; 88:90410 .

15. Delobel-Ayoub M, Karninski M, Marret S. Behavioral outcome at 3 years of age in very preterm infants: The EPIPAGE Study. Pediatrics 2006; 117:1996-2005.

16. Biederman J, Faraone SV, Monuteaux MC, Plunkett EA, Gifford J, Spencer T. Growth deficits and attention-deficit/ hyperactivity disorder revisited: Impact of gender, development, and treatment. Pediatrics 2003; 111:10106.

17. Stein REK, Siegel MJ, Bauman LJ. Are children of moderately low birth weight at increased risk for poor health? A new look at an old question. Pediatrics 2006; 118:21723.

18. Burgess JR, Stevens L, Zhang W, Peck L. Long chain polyunsaturated fatty acids in children with attentiondeficit hyperactivity disorder. Am J of Clin Nutr 2000; 71:327-30. 